\title{
Synthesis of Imidazole-Based Medicinal Molecules Utilizing the van Leusen Imidazole Synthesis
}

\author{
Xunan Zheng ${ }^{1,2}$, Zhengning Ma ${ }^{1,3}$ and Dawei Zhang ${ }^{1, *(1)}$ \\ 1 College of Chemistry, Jilin University, Changchun 130012, China; zhengxn8217@mails.jlu.edu.cn (X.Z.); \\ 2019203060028@whu.edu.cn (Z.M.) \\ 2 College of Plant Science, Jilin University, Changchun 130062, China \\ 3 Key Laboratory of Combinatorial Biosynthesis and Drug Discovery (Ministry of Education), School of \\ Pharmaceutical Sciences, Wuhan University, Wuhan 430071, China \\ * Correspondence: z_dw@jlu.edu.cn; Tel.: +86-431-8783-6471
}

Received: 10 February 2020; Accepted: 1 March 2020; Published: 3 March 2020

\begin{abstract}
Imidazole and its derivatives are one of the most vital and universal heterocycles in medicinal chemistry. Owing to their special structural features, these compounds exhibit a widespread spectrum of significant pharmacological or biological activities, and are widely researched and applied by pharmaceutical companies for drug discovery. The van Leusen reaction based on tosylmethylisocyanides (TosMICs) is one of the most appropriate strategies to synthetize imidazole-based medicinal molecules, which has been increasingly developed on account of its advantages. In this review, we summarize the recent developments of the chemical synthesis and bioactivity of imidazole-containing medicinal small molecules, utilizing the van Leusen imidazole synthesis from 1977.
\end{abstract}

Keywords: van Leusen; TosMICs; imidazole; synthesis

\section{Introduction}

Imidazole ring, which is widely found in natural products and medical molecules, is one of the most prominent, five-membered, nitrogen-containing, heterocyclic scaffolds. Furthermore, imidazole-based heterocyclic compounds, which possess a vital position in medicinal chemistry, have been playing a central role in the treatment of numerous types of diseases, and new derivatives for medicinal use are being energetically developed worldwide [1-5]. Due to the peculiar structural characteristic of imidazole scaffold with a worthy electron-rich feature, it is advantageous for imidazole groups to combine with various receptors and enzymes in biological systems, through diverse weak interactions, thereby showing a variety of biological activities. At present, a legion of imidazole-containing compounds with high a medical potential as a clinical drug have been widely used to treat diverse types of illnesses, such as antibacterial [6,7], antifungal [8,9], anti-inflammatory [10,11], antiviral [12,13], anti-parasitic [14,15], anticancer [16,17], antihistaminic [18,19], and enzyme inhibition [20,21]. Imidazole and its derivatives encompass a vast range of medical activities, as shown in the following Table 1. 
Table 1. Various pharmacological activities and chemical structures of imidazole-based molecules.

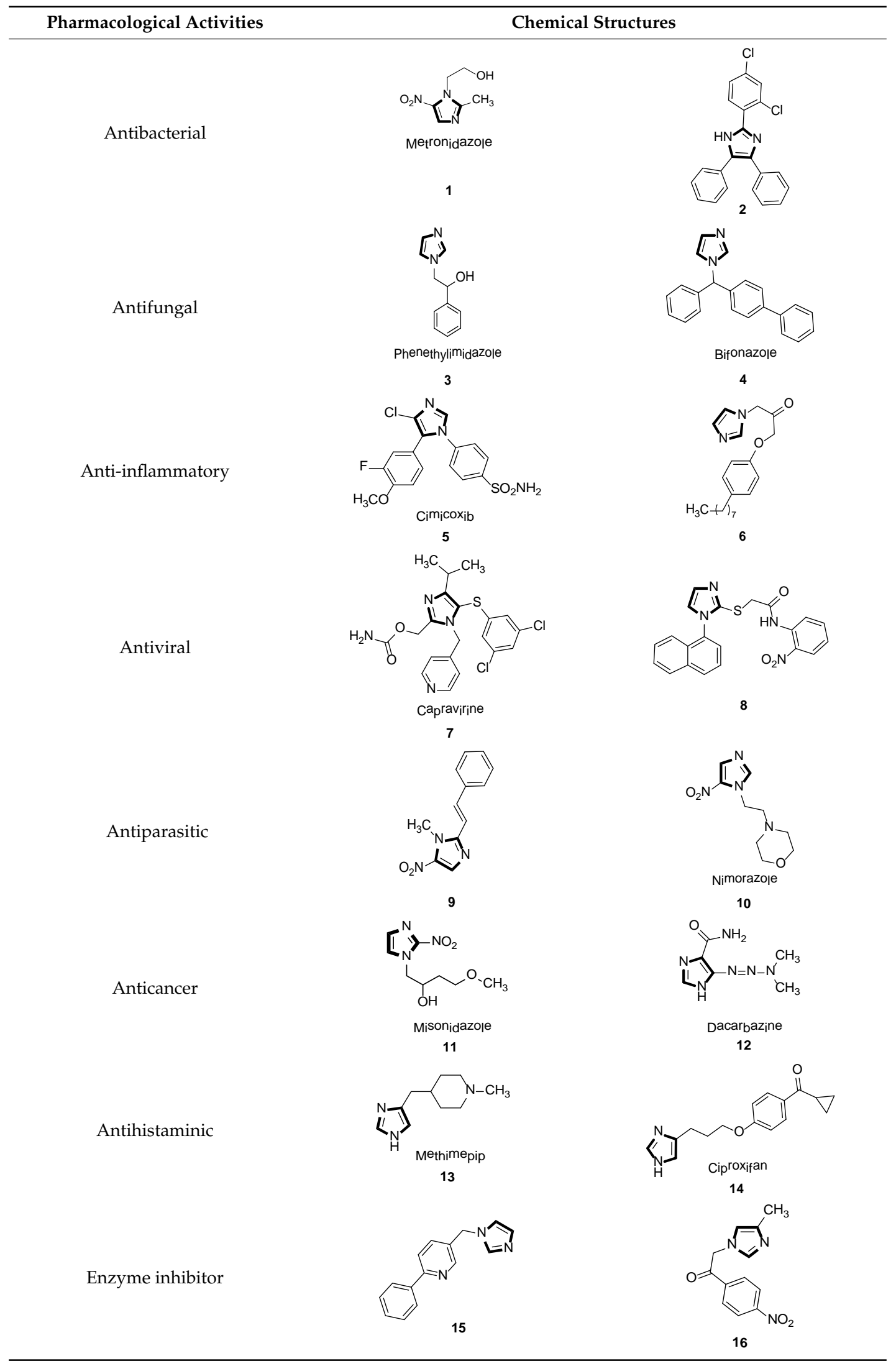


Owing to the significant pharmacological or biological activities and the enormous medicinal value of imidazole-based molecules, the synthesis of the imidazole-skeleton small molecule has been paid attention to by pharmaceutical chemists and organic synthesis researchers. However, there is still a need for a simple and efficient way to construct the imidazole heterocyclic skeleton. In recent decades, there have been numerous classical strategies for synthesizing this ring compound in the laboratory, including van Leusen imidazole synthesis [22], Debus-Radziszewski imidazole synthesis [23], Wallach imidazole synthesis [24], etc. Among these synthetic strategies, it is well-known that the van Leusen imidazole synthesis based on TosMICs, which is the cycloaddition reaction, is one of the most convenient and attractive protocols for the preparation of imidazole-based small molecules, due to its excellent advantages like simple manipulation, easily obtained raw materials and a wide range of substrates, which has been developed rapidly in the past decades (Scheme 1).

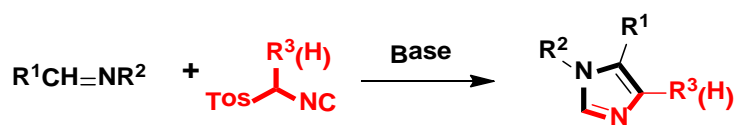

Scheme 1. General van Leusen imidazole synthesis.

TosMIC, one of the most significant reactants, has many good features at room temperature, including being a stable solid and being odorless and colorless. Since it was introduced and applied in organic synthesis by the Dutch professor van Leusen in 1972, this reagent is also known as van Leusen's reagent. Up to now, TosMIC and its derivatives have been recognized as one of the most significant building blocks in nitrogen heterocyclic synthesis, which have been fruitfully employed especially in the preparation of imidazole-based heterocycles [25-29].

Therefore, this review will summarize the developments of the synthesis of imidazole-based molecules, utilizing the van Leusen imidazole synthesis, based on TosMICs from 1977. It is expected that this review article will be beneficial for new opportunities to search for a reasonable design for less toxic and higher bioactive imidazole-containing drugs.

\section{General van Leusen Imidazole Synthesis}

In 1977, van Leusen et al. first published that TosMIC and aldimine undergo a base-induced cycloaddition reaction in a proton solvent, meanwhile, the effects of $R^{1}$ and $R^{2}$ on the formation of $\mathbf{1 7}$ were qualitatively analyzed. They discovered that $\alpha$-tosylbenzyl isocyanate and $\alpha$-tosylethyl isocyanate 18 could form 1,4,5-trisubstituted imidazoles 19 (Scheme 2). Based on the various advantages of this reaction, it is widely named as the van Leusen imidazole synthesis [22].

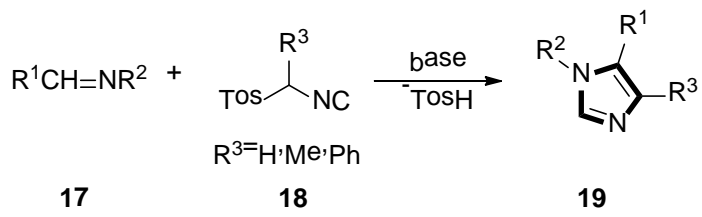

Scheme 2. The first example of van Leusen imidazole synthesis.

As shown in Scheme 3, the van Leusen imidazole synthesis allows the preparation of imidazole through [3 + 2] cycloaddition reaction from aldimines and a reaction with TosMICs, which contain reactive isocyanide carbons, active methylene, and leaving groups such as C2N1 "3-atom synthon". The cyano moiety can be a gradual cycloaddition to polarize a double bond under a base condition. The elimination of $p$-TosOH forms the intermediate 4-tosyl-2-imidazoline to produce the target 1,4,5-trisubstituted imidazoles $\mathbf{1 9}$, accompanied by the elimination of $p-\mathrm{Tos} \mathrm{OH}$, which is negative to the obtained 1,5-disubstituted imidazoles. 


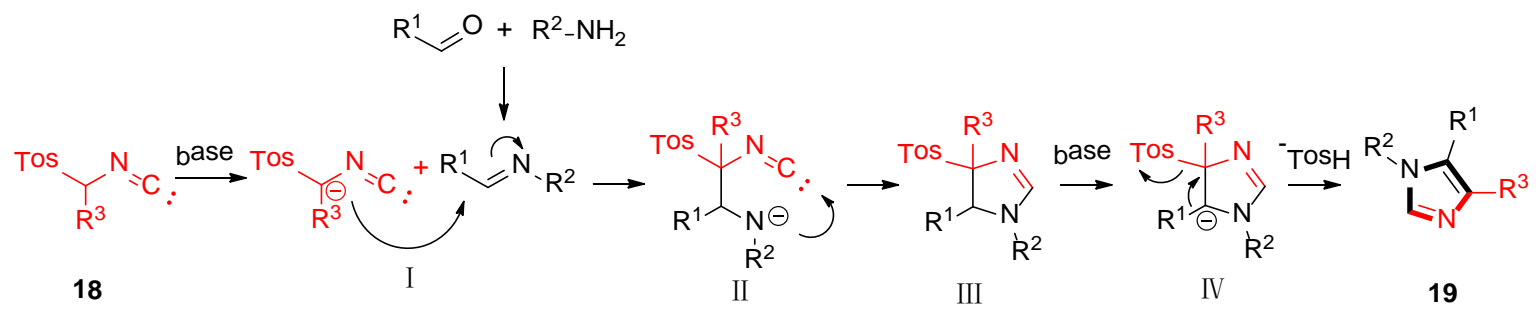

Scheme 3. Mechanism of van Leusen imidazole synthesis.

\section{Developments of the van Leusen Imidazole Synthesis}

In 1995, Frankowski and co-workers were reported to lead the known $D$-xylo-pentodialdose to form imidazo- $L$-xylo-piperidinose derivatives, based on a sequential eight-step reaction. In this process, the imidazole-base molecule was obtained through a van Leusen reaction as a key step. As shown in Scheme 4, applying this van Leusen methodology, 20 and TosMIC 18 were transformed into the imidazole derivative 21. At last, removal of the protecting group gave to the target product 22, which is a kind of bicyclic azasugar and a glycosidase inhibitor [30].

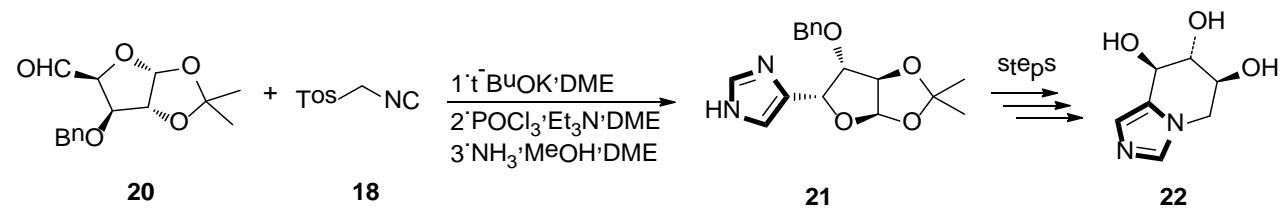

Scheme 4. The van Leusen methodology as the key step to synthesize glycosidase inhibitor 22 .

In 1998, the Sisko group synthesized the 1,4,5-trisubstituted imidazole 25, which displayed potent binding with p38 MAP kinase, a recently discovered protein kinase that participates in an inflammation regulatory mechanism. As shown in Scheme 5, 1,4,5-trisubstituted imidazole 24 was accessed by a novel and facile protocol, based on the reaction of an $\alpha$-ketoaldimine $\mathbf{2 3}$ with an aryl-substituted TosMIC reagents $\mathbf{1 8}$ as the key step [31].

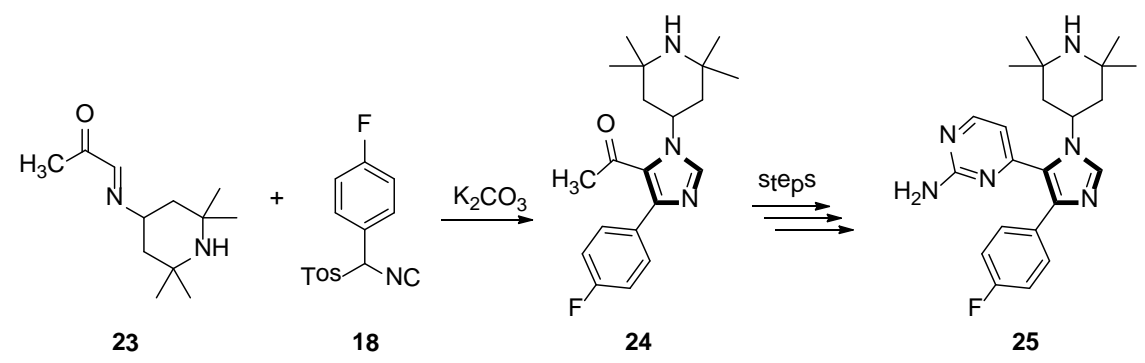

Scheme 5. Synthesis of imidazole 25 exhibiting potent binding with p38 MAP kinase.

In 2000, they also described an active and gentle procedure for preparing multisubstituted imidazoles in one-pot, from an aryl-substituted TosMIC and a generated imine, in situ. One of the reactions is shown in Scheme 6, cycloaddition of imine 28, prepared imine in situ from a $40 \%$ aqueous solution of pyruvaldehyde 26 and amine 27 , then, ketone 29 was prepared in DMF, using aryl-substituted TosMIC 18 and $\mathrm{K}_{2} \mathrm{CO}_{3}$, with a $75 \%$ yield. Surprisingly, when the reaction was carried out at $0{ }^{\circ} \mathrm{C}$, the product 29 was blended with 15-20\% of the 1,4-disubstituted imidazole 30 [32]. 


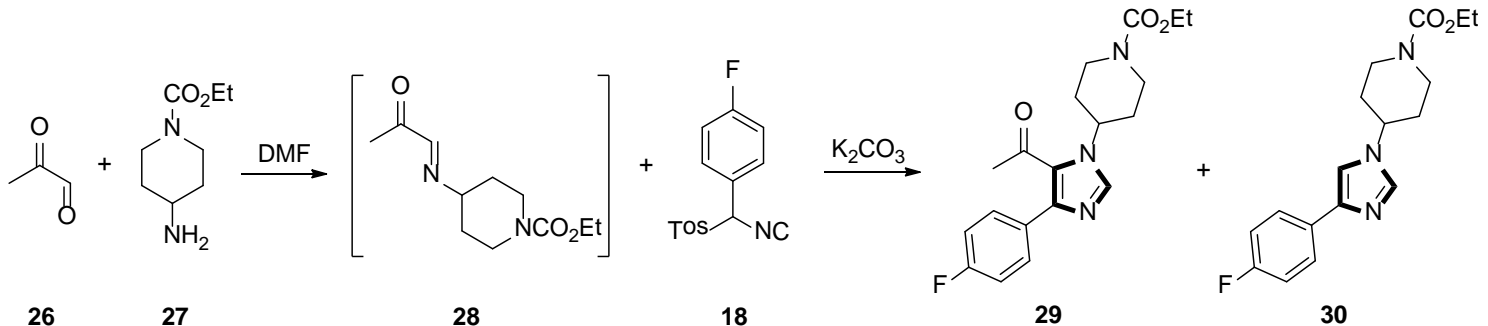

Scheme 6. Synthesis of ketone 29 and 1,4-disubstituted imidazole 30.

In the same year, the Vanelle group converted 6-nitropiperonal into the methylimine 31 through a condensation reaction with methylamine in ethanol. The molecule with imidazole ring $\mathbf{3 2}$ was formed by reacting equimolar quantities of TosMIC 18 and aldimine 31 with $\mathrm{K}_{2} \mathrm{CO}_{3}$ in methanol solvent, under a refluxing condition. Then, through the classical Knoevenagel reaction, compound 33 were obtained, which displayed an effective in vitro leishmanicidal bioactivity (Scheme 7). Compound 33a, higher in vitro leishmanicidal bioactivity, might lead to a promising significant therapeutic agent (Scheme 8) [33].
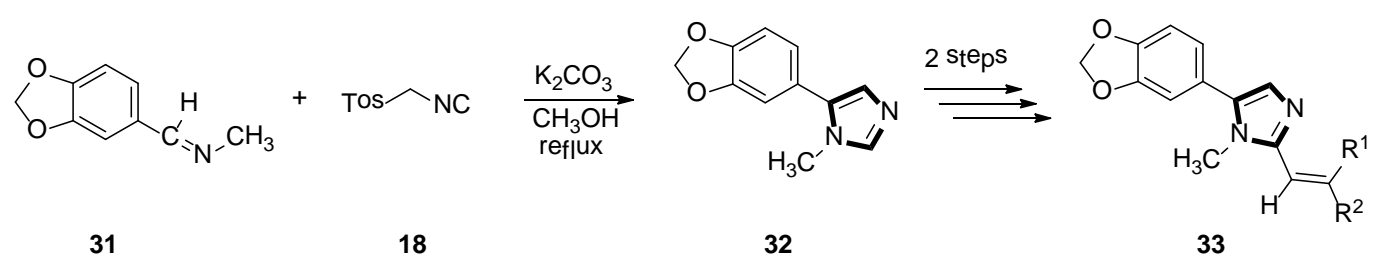

Scheme 7. Synthesis of the potential significant therapeutic agent 33.<smiles>C/C(=C\c1ncc(-c2ccc3c(c2)OCO3)n1C)[N+](=O)[O-]</smiles>

$33^{a}$

Scheme 8. High in vitro leishmanicidal activity of compound 33a.

From 2005 to 2006, in order to access unusual imidazole-based heterocyclic structures, a series of experimental results were reported by the Gracias and Djuric group.

Initially, they reported a new protocol employing the van Leusen three-component reaction and the ring-closing metathetical reaction in a sequence method, to form a fused bicyclic imidazole ring. The general method is shown in Scheme 9 (top), the reaction underwent smoothly with the condensation reaction of 4-pentenal 34 and allylamine 35, in DMF at room temperature, to give the imine in situ, which was followed by the addition of the TosMIC reagent 18 and a base, to access the van Leusen imidazole product 36 in high yield. Next, a ring-closing metathesis (RCM) reaction was performed through the second-generation Grubbs catalyst to get imidazole 37 and their derivatives (Scheme 9, top) [34].

Next, they developed a concise route of fused imidazo azepine analogs via the stepwise van Leusen/intramolecular enyne metathesis synthesis. The condensation reaction of 4-pentenal 34 with but-2-yn-1-amine 38 in DMF at room temperature gives the imine in situ, and then adds phenyl TosMIC 18 and $\mathrm{K}_{2} \mathrm{CO}_{3}$ to access the van Leusen imidazole product 39 in high yield. Subsequent cyclization via the intramolecular enyne metathesis reaction results in the formation of the cyclized product 40 containing the diene functional group and their derivatives (Scheme 9, bottom) [35]. 


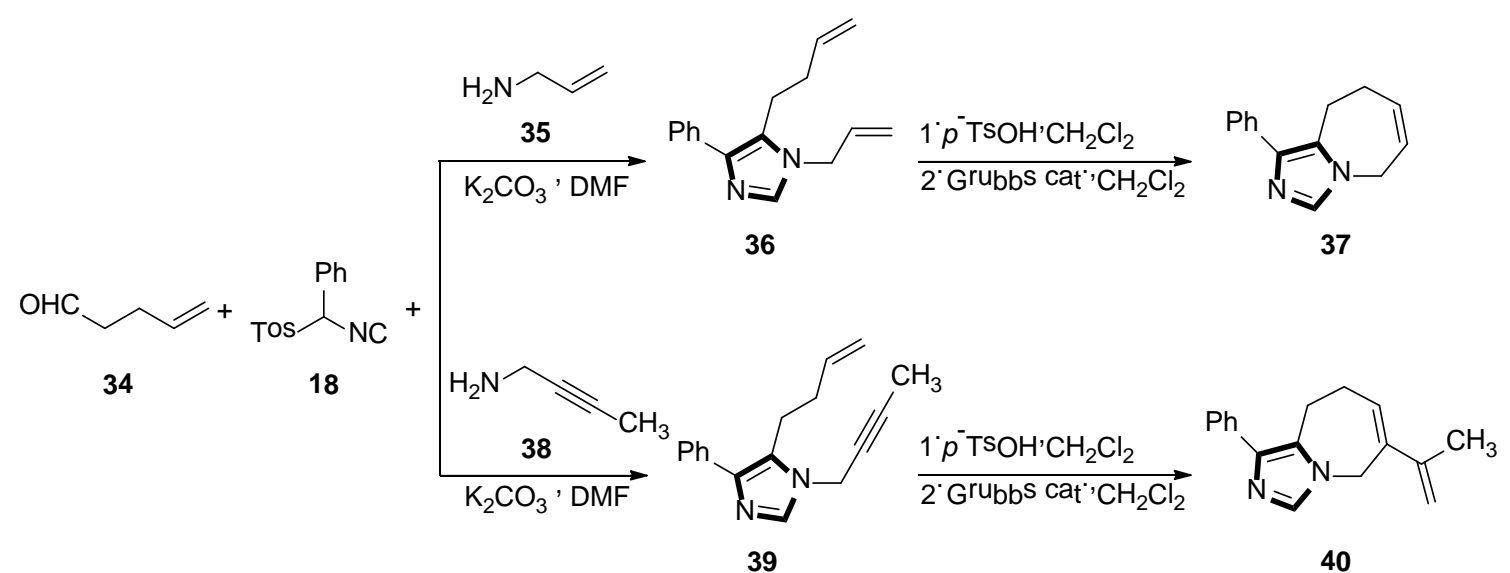

Scheme 9. Synthesis of the fused bicyclic 37 and the fused imidazo azepine derivatives $\mathbf{4 0}$.

In late 2005, they also reported a facile route of fused triazolo imidazole derivatives via a sequential van Leusen/alkyne-azide cycloaddition reaction. The use of an azide functionality on the aldehyde $\mathbf{4 1}$ and an alkyne functionality on the amine $\mathbf{4 2}$ gives the bifunctional raw material for the van Leusen reaction resulting in substrate 43 . Subsequent cyclization through the intramolecular alkyne-azide cycloaddition will form the fused triazolo imidazole skeletons $\mathbf{4 4}$ (Scheme 10) [36].<smiles>[R]C#CCn1cnc(-c2ccc([R])cc2)c1-c1ccc[R1](C)c1N</smiles>

Scheme 10. Synthesis of fused triazolo imidazoles 44 .

Then in 2006, they continued to publish the methods for the fused imidazole ring synthesis by using the tandem van Leusen/RCM, van Leusen/enyne metathesis, van Leusen/alkyne-azide cycloaddition, or van Leusen/Heck reaction, respectively.

Firstly, they synthesized fused imidazo-pyridine and imidazo-azepine derivatives by using a sequential van Leusen/ intramolecular Heck route. The imidazole 47 and 49 were accessed via the condensation reaction between an appropriate aldehyde-containing vinylogous bromide 45 and an amine-containing double bond 46, respectively. Then, preformation of the imine, the desired TosMIC reagent 18 and $\mathrm{K}_{2} \mathrm{CO}_{3}$ were added, and the cyclization was allowed to proceed at room temperature to get imidazo-[1,5-a]pyridine 48 or imidazo[1, 5-a]azepine 50 (Scheme 11) [37].

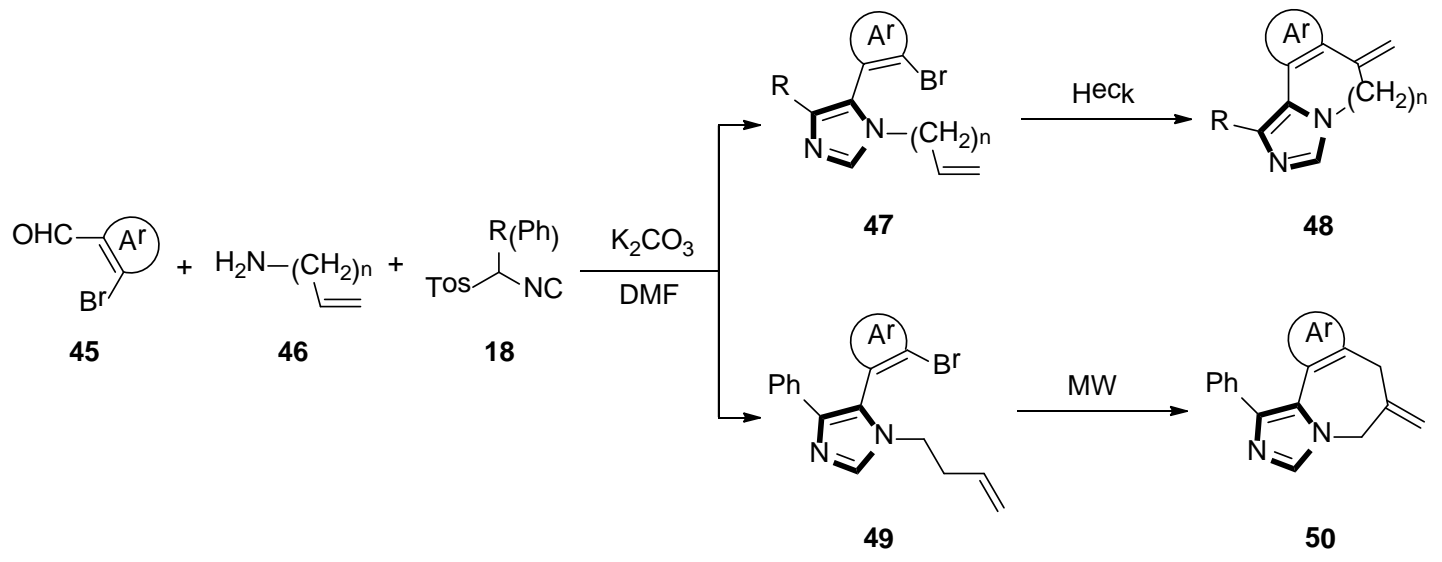

Scheme 11. Synthesis of the fused imidazole rings 48 and 50. 
Next, they described an elegant method to obtain a fused imidazole ring, employing the van Leusen three-component reaction, followed by $\mathrm{Pd} / \mathrm{Cu}$ catalyzed intramolecular $\mathrm{C}$-arylation. Meanwhile, another available protocol to form 5,6-dihydroimidazo[2,1-a]-isoquinoline system 53, via a radical cyclization reaction of tethered aryl halides onto the imidazole ring, was also published. In their article, the imidazole precursors were accessed through an alkylation chemistry, and the van Leusen reaction was used to assemble imidazole followed by a transition metal catalyzed C-C bond framework (Scheme 12) [38].

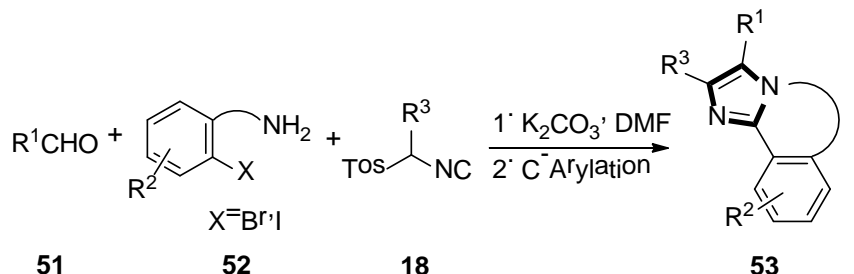

Scheme 12. Synthesis of fused imidazole rings 53.

In 2006, Dömling's group reported that substituting pyrroloimidazoles 56 were assembled by van Leusen multicomponent reaction (MCR) of TosMIC 18, indole carbaldehydes 54 , and primary amines 55. They were interested in bioactivity of the products and these imidazole-containing skeletons were screened in a phenotypic assay for neurite outgrowth. The test results indicated that these small molecules would serve as useful chemical probes to research neurite growth and might be used as a therapeutic application for axon regeneration of lesions of the human spinal cord and brain (Scheme 13) [39].

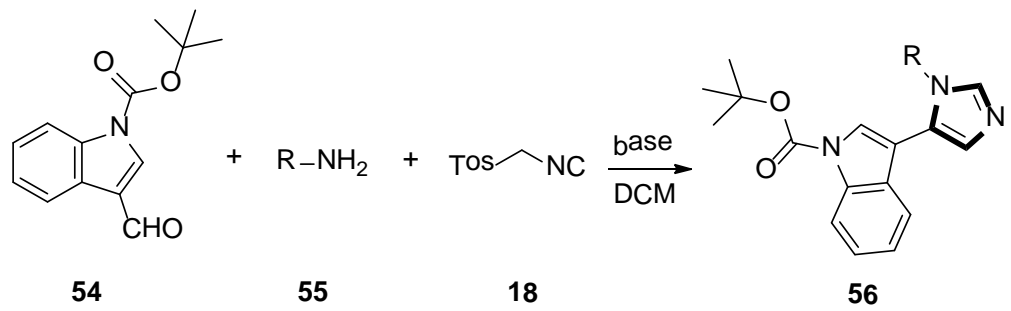

Scheme 13. Synthesis of chemical probes 56.

Based on their previous research, they also reported a novel synthesis route of potential aspartyl-protease inhibitors in 2007. In their method, 1,4,5-trisubstituted 1-(4-piperidyl)-imidazoles 59 could be obtained through an isocyanide-based van Leusen MCR of $\alpha$-substituted TosMICs 18, aldehydes 57, and 4-aminopiperidine 58 (Scheme 14) [40].

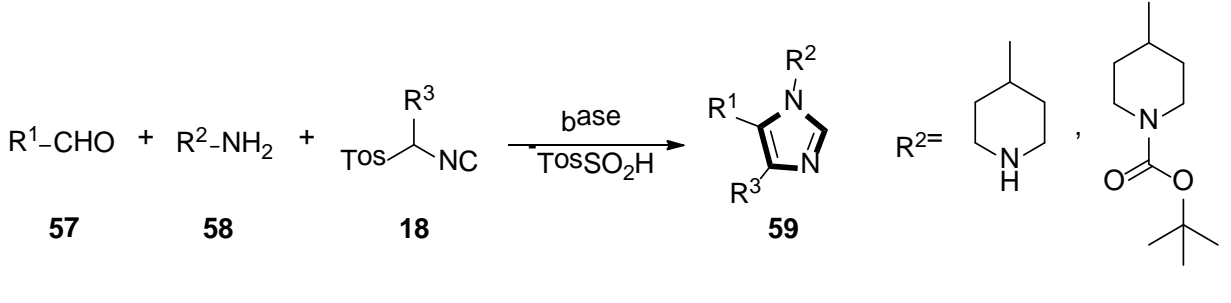

Scheme 14. Synthesis of potential aspartyl-protease inhibitors 59.

In 2009, a range of 1,5-disubstituted-4-methylimidazole preparations were reported by Fodili and co-workers. Compounds 63 were prepared from acetimine analogs 62 , which were obtained from dehydroacetic acid 60 and primary amine 61 . These were enabled to react with TosMIC 18 in the presence of catalytic amounts of bismuth triflate. A plausible mechanism was put forward that 
involved the first formation of an imidazoline intermediate, followed by methyl migration, and then subsequent aromatization provided access to the target imidazole ring (Scheme 15) [41].

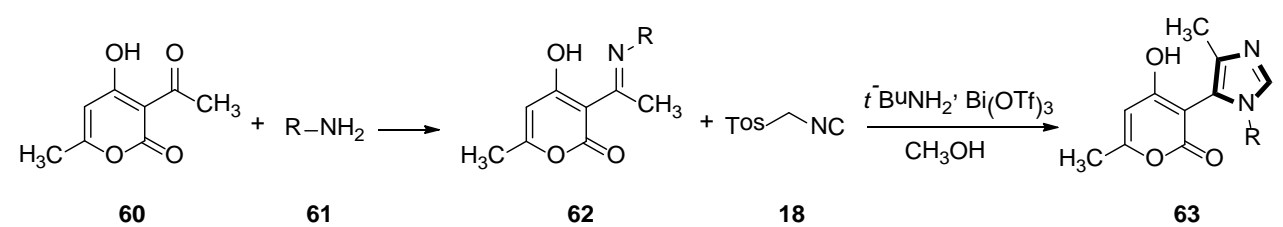

Scheme 15. Synthesis of 1,5-disubstituted-4-methyl imidazoles 63.

In 2012, Hulme and Moliner reported a novel synthesis of two pharmacological relevant classes of molecules forming the imidazoquinox aline scafflod 66 and 68 , respectively. This method involves the use of 1,2-phenylenediamines 64 and glyoxylic acid derivatives, namely ethyl glyoxylate 65 or benzylglyoxamide 67, along with TosMIC 18 in a microwave-assisted van Leusen three-component condition. Then there was a deprotection-cyclization step to form two biological-activity-enticing imidazoquinoxaline families (Scheme 16) [42].

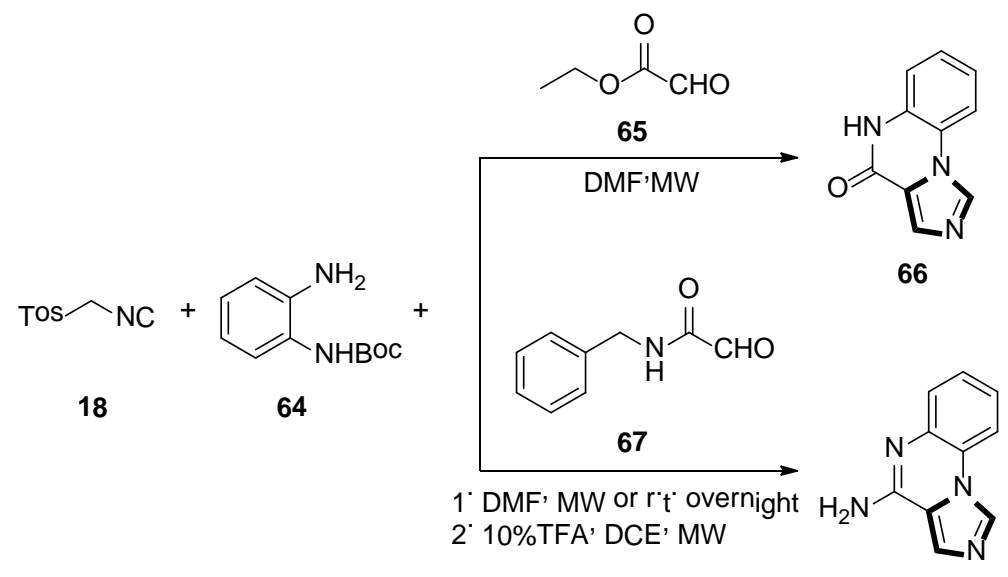

68

Scheme 16. Synthesis of biologically enticing imidazoquinoxaline 66 and 68 .

In 2016, the Pirali's group reported a method for synthesizing 4-PI analogues via the van Leusen MCR, which is by far the most direct method for obtaining functionally rich imidazole. This transformation can be used to synthesize four different series of compounds-1,4,5-trisubstituted and 1,5-, 1,4- and 4,5-disubstituted imidazoles 71. Meanwhile, 4,5-diaryl imidazoles were analyzed by a 3D quantitative structure-activity relationship (SAR). Based on their docking score and synthetic feasibility, the compounds were selected, synthesized, and biologically evaluated. Compared with 4-PI, the IDO1 inhibitor products through this experimental method have enhanced the potency. Both in enzymatic and cellular assays, the most active compounds showed lower micromolar potency, but no detectable cellular toxicity. The analysis displayed that a putative hydrogen bond between the Ser167 of the protein and the $\mathrm{NH}$ of the imidazole ring might be responsible for the improvement of the potency, together with favorable interactions with the partially occupied pocket $\mathrm{B}$. The results above suggested that the 4,5-disubstituted imidazole framework might give a new orientation for the design of IDO1 inhibitors, in future (Scheme 17) [43].

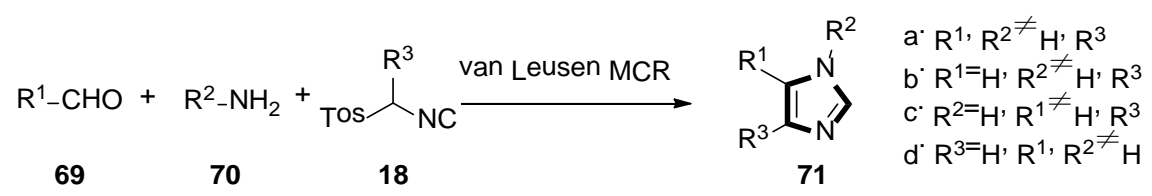

Scheme 17. Synthesis of potential IDO1 inhibitors 71. 
At the same year, the Suresh group developed a direct, sequential, copper-catalyzed $\mathrm{N}$-arylation-condensation reaction utilizing chiral cyclic 1,2-diamines 73 and ortho-haloaryl aldehydes or ketones $\mathbf{7 2}$. The corresponding chiral tricyclic 1,4-benzodiazepines $\mathbf{7 4}$ were synthesized in high yield. Subsequently, 1,4-diazapine 75 was converted into a novel tetracyclic $N$-fused ImBDs through van Lusen imidazole synthesis (Scheme 18) [44].

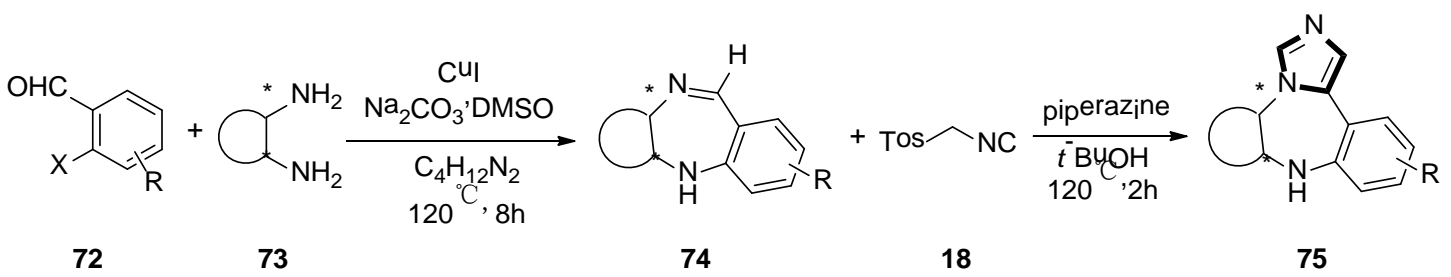

Scheme 18. Synthesis of $N$-fused ImBDs 75.

A range of 5-aryl-1-alkylimidazole derivantes 79 were synthetized by utilizing the van Leusen MCR by Bojarski and co-workers, in 2017. The van Leusen reaction was performed by the stepwise cycloaddition of TosMIC 18 to the polarization double bond of a preformed imine 78. Imidazole is synthetized by the elimination of $p-\mathrm{Tos} \mathrm{OH}$, from the cyclic intermediate. Then, aromatic aldehydes bind to the appropriate amine. All compounds were highly selective to 5-HT5A. These compounds were metabolically stable in human liver microsome, showed less toxicity in HEK-293 and HepG2 cells and were water-soluble (Scheme 19) [45].

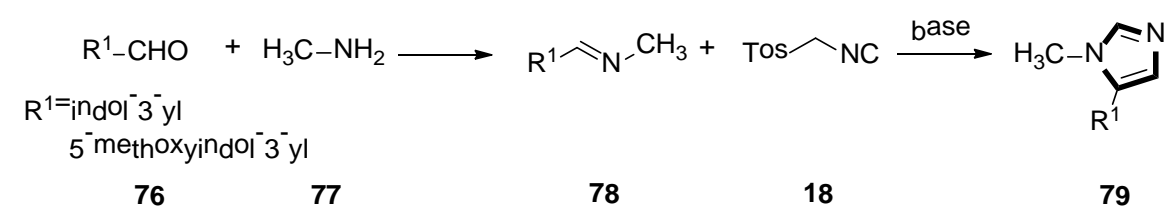

Scheme 19. Synthesis of 5-HT7 receptor agonists 79.

In 2019, they also synthesized a range of fluorinated indole-imidazoles to find more effective 5-HT7 receptor selective agonists as molecular probes. As shown in Scheme 20, the target compounds 82 were obtained from the relevant indoles undergoing the formylation process and the stepwise van Leusen imidazole synthesis with TosMIC 18. Meanwhile, they indicated that compound 82a might be a potential analgesic or a long-sought tool for studying the receptor effect of 5-HT7, based on the anti-nociceptive function on a murine model of neuropathic pain (Scheme 21) [46].

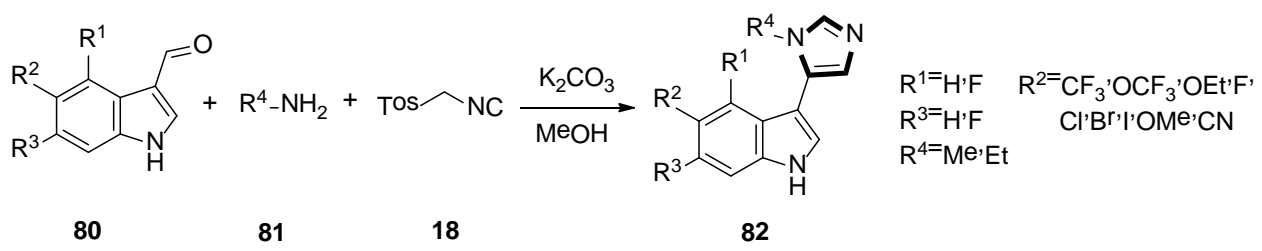

Scheme 20. Synthesis of 5-HT7 receptor low-basicity agonists 82 .

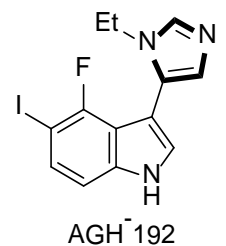

$82 a$

Scheme 21. A potential analgesic 82a. 
In 2017, Sharma and co-workers developed a brief, novel, and simple operational van Leusen method. They presented the first van Leusen process towards synthesis of high functionalized dihydrodibenzo[b,f]imidazo[1,2-d] [1,4] thia/oxazepine 86, by reacting TosMIC 18 and dibenzo[b,f] [1,4] thia/oxazepines 85, which were obtained from compound 83 and 84 , under a basic condition (Scheme 22) [47].

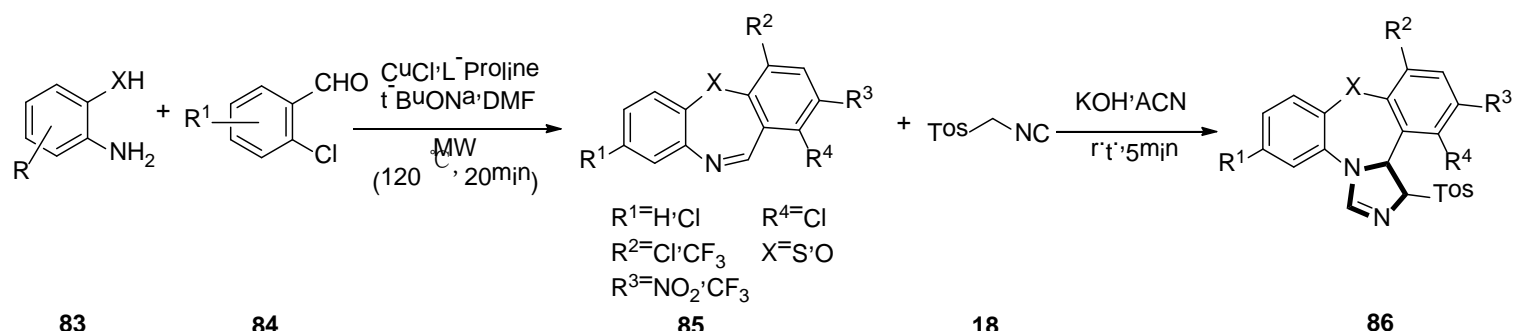

Scheme 22. Synthesis of highly functionalized molecules 86 .

In 2018, the Weaver group reported that two corresponding series of molecules based on the SAR design-N1-substituted 5-indoleimidazoles and N1-substituted 5-phenylimidazoles were accessed. The latter (and more efficient) series were obtained by an accidental rearrangement of imines that are intermediate in the van Leusen imidazole synthesis reaction. The one-pot synthesis of compounds 89 in two steps utilizing the van Leusen imidazole synthesis process is shown in Scheme 23. First, imine formation between 2-indolecarboxaldeyde 87 and the appropriate benzyl amine 88 took place, which then reacted with TosMIC 18 and $\mathrm{K}_{2} \mathrm{CO}_{3}$ to give indoleimidazoles. They have also conducted SAR studies on their novel and more potent compounds. Compounds 92 were synthesized starting from known amine 91 and aromatic aldehyde 90 (Scheme 24). These inhibitors represent a promising future for the development of IDO1 inhibitors with specific physical and chemical properties that are easy to synthesize [48].

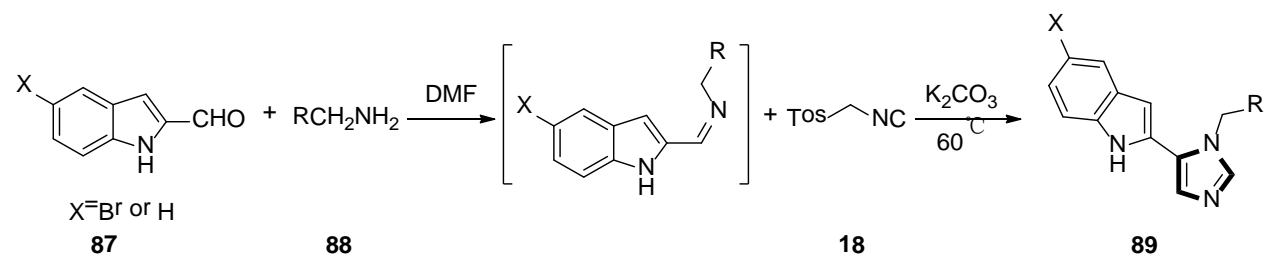

Scheme 23. One-pot synthesis of potential IDO1 inhibitors 89.

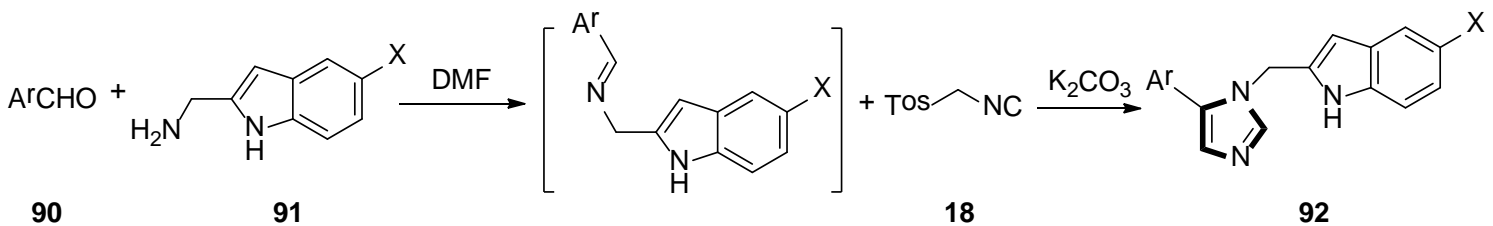

Scheme 24. One-pot synthesis of potential IDO1 inhibitors 92.

In the same year, Kondaparla et al. synthetized a range of short chain 4-aminoquinoline-imidazole derivatives 95 using two steps, in one-pot, via the van Leusen MCR standard method. The detailed synthetic protocol for the synthesis of target compounds 95 is shown in Scheme 25, compound 94 as amine was utilized to react with TosMIC 18 and acetaldehyde 93 through a multicomponent cyclisation reaction. In the end, all synthesized compounds were screened against the chloroquine sensitive and chloroquine-resistant strains of Plasmodium falciparum. In this study, substitution on the $N$-(2-(1H-imidazol-1-yl)ethyl)-7-chloroquinolin-4-amine moiety had greatly influenced the antiplasmodial bioactivity [49]. 


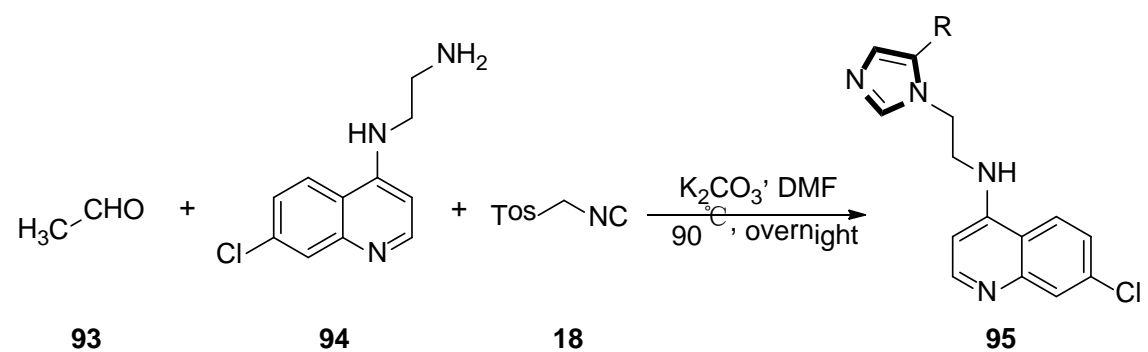

Scheme 25. One-pot synthesis of antiplasmodial compounds 95.

In the same year, Laali and co-workers reported that an available route provided access to various C5-substituted imidazoles 97, 98, and 99, through one-pot tandem via the van Leusen-Suzuki, van Leusen-Heck, and van Leusen-Sonogashira methods, respectively. Imidazolium-ILs as solvents, along with piperidine-appended imidazolium [PAIM] $\left[\mathrm{NTf}_{2}\right]$ as task-specific basic IL and facile aldimines 96, and TosMIC 18 in the mild condition, were employed in their article (Scheme 26) [50].

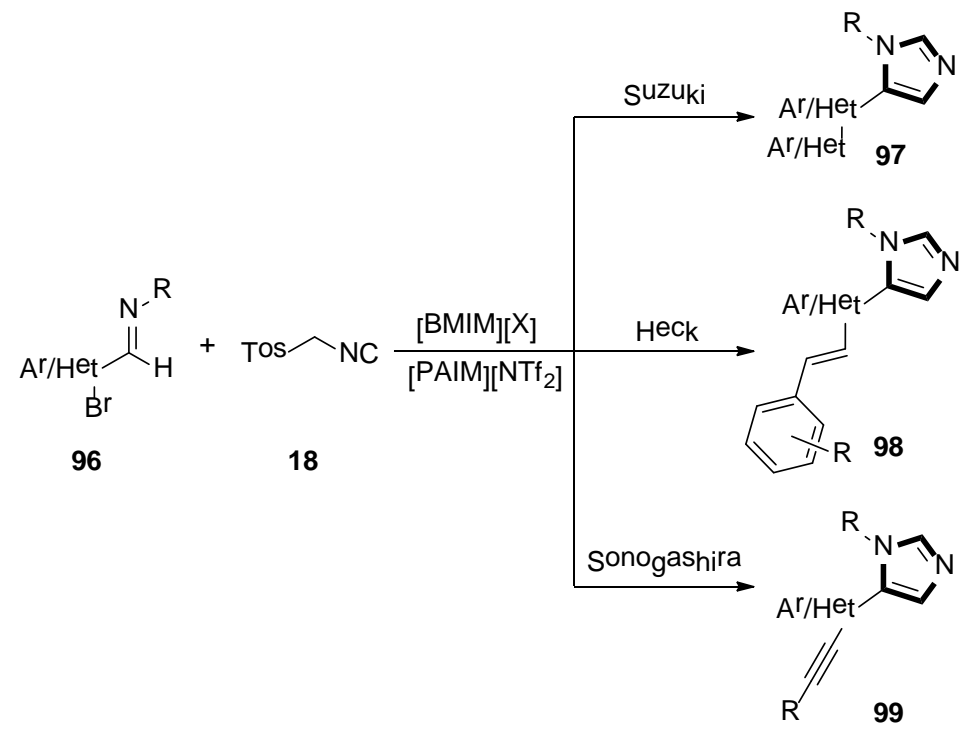

Scheme 26. Synthesis of C5-substituted imidazoles 97, 98, and 99.

In the late 2018, Guan and co-workers developed a novel and highly efficient synthesis of polysubstituted $1 H$-imidazo-[4,5-c] quinoline derivatives through the stepwise van Leusen/Staudinger/ aza-Wittig/carbodiimide-mediated cyclization method. Azides 102 were accessed by the van Leusen reaction of 2-azidobenzaldehyde 100, amine 101, and TosMIC 18. Then, $1 H$-imidazole-[4,5-c] quinoline 103 was formed by a tandem aza-Wittig reaction with isocyanate, in a moderate to good yield (Scheme 27) [51].

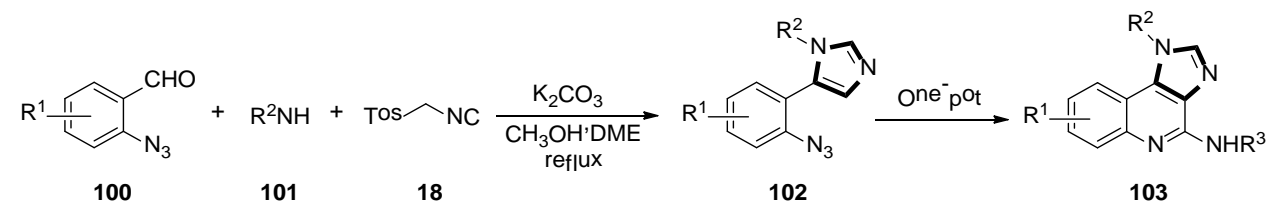

Scheme 27. Synthesis of polysubstituted quinoline derivatives 103.

In 2019, Lammi et al. reported an imidazolyl peptidomimetic, which has shown proprotein convertase subtilisin/Kexin 9 (PCSK9) inhibitor bioactivity in the micromolar dosage range. As shown in Scheme 28, the first imidazole derivative 105 was accessed in good yield, starting from $p$-anisaldehyde 104, methylamine 77, and TosMIC 18. Then, compound 105 was treated with $n$-butyllithium and 
$\mathrm{DMF}$ as a formylating reagent at low temperatures, to obtain the aldehyde derivative 106 in high yield. The target compounds 107a RIm13 and 107b RIm14 were accessed via a quasi-iterative protocol, with the emphasis on the alternating van Leusen three-component reactions with two formylation steps. In the end, they found that RIm13 represents currently one of the most potent proprotein convertase subtilisin/kexin 9/low-density lipoprotein receptor, (PCSK9/LDLR) protein-protein interaction of small molecules (Scheme 28) [52].<smiles>COc1ccc(C2CN=C(C=O)N2C)cc1</smiles>

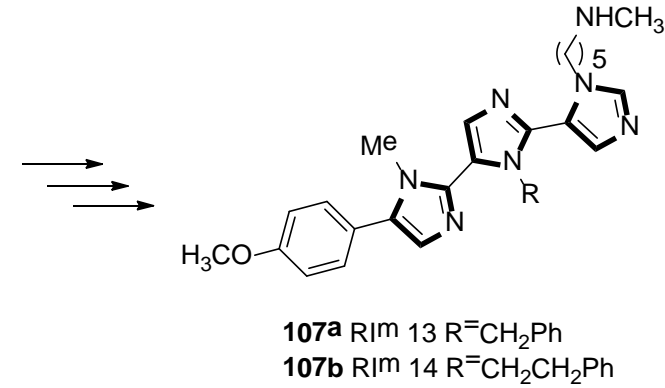

Scheme 28. Synthesis of inhibitory activity molecules 107 a and $\mathbf{1 0 7 b}$.

In 2020, Rashamuse and co-workers described a microwave-assisted cycloaddition of TosMIC 18 with imines and aldehydes to form 1-substituted 5-aryl-1H-imidazoles. Imidazoles 110 were also obtained in a one-pot, two-steps reaction with a yield comparable to that obtained through step-by-step irradiation of aldehyde 108 and aliphatic amine 109, with a neat microwave at $60{ }^{\circ} \mathrm{C}$ for $4 \mathrm{~min}$, followed by the addition of TosMIC 18, $\mathrm{K}_{2} \mathrm{CO}_{3}$, and $\mathrm{CH}_{3} \mathrm{CN}$, and the reaction mixture was placed under microwave conditions (Scheme 29) [53].

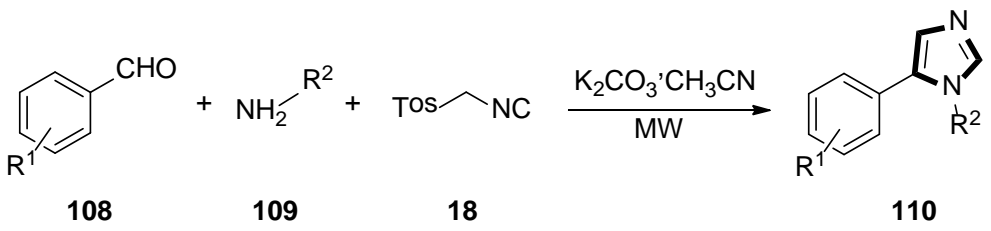

Scheme 29. Synthesis of a novel class of potential inhibitors of microbial pathogen $\mathbf{1 1 0 .}$

Moreover, the antibacterial properties of these fragments in vitro were tested by the minimum inhibitory concentration (MIC) bioassay. The results showed that the MIC value of compound 110a against Staphylococcus aureus was $15.6 \mu \mathrm{g} / \mathrm{mL}$, while $\mathbf{1 1 0 b}$ displayed a similar MIC value against Bacillus cereus, and indicated that these compounds might be further developed to specifically target microbial pathogens (Scheme 30).<smiles>CCCCn1cncc1-c1ccc(C(C)(C)C)cc1</smiles>

$110^{\mathrm{a}}$<smiles>CC(C)(C)c1ccc(-c2cncn2C2CCCCC2)cc1</smiles>

110b

Scheme 30. Antimicrobial compounds 110a and 110b. 
In 2014, the Bunev group reported a novel process for the synthesis of 1,4,5-trisubstituted imidazole-containing trifluoromethyl group 112, which contained two-component condensation reaction, $N$-aryltrifluoroacetimidoyl chlorides 111 reacted with TosMIC 18, as well as sodium hydride in dry THF at room temperature, under argon atmosphere (Scheme 31, top) [54].

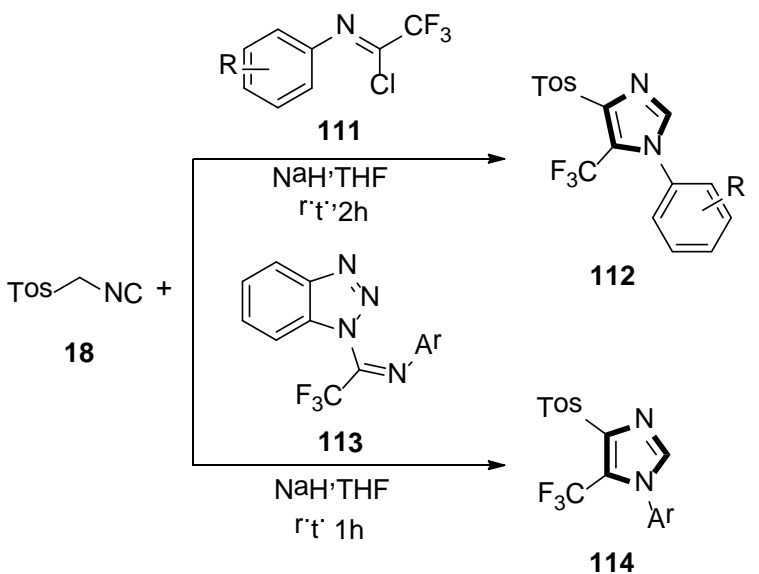

Scheme 31. Synthesis of imidazoles 112 and 114 containing the trifluoromethyl group.

Then, in 2019, they also previously described a procedure, in which 1-imidoylbenzotriazoles [N-aryl-1-(1H-benzotriazol-1-yl)-2,2,2-trifluoroethan-1-imines] 113 reacted with TosMIC 18, according to the van Leusen reaction to obtain a good yield of 1-aryl-4-(4- methylbenzenesulfonyl)-5(trifluoromethyl)-1H-imidazoles 114, which is difficult to access. The yield of 114 almost did not depend on the substituent in the $N$-aryl fragment of initial imidoylbenzotriazole 113 (Scheme 31, bottom) [55].

A possible mechanism for synthesis of the imidazole-containing trifluoromethyl group is shown in Scheme 32. Initially, deprotonation of TosMIC with sodium hydride forms stabilized carbanion 18, which attacks the carbon-nitrogen bond's carbon atom of 115, to give the intermediate adduct 116. Elimination of the $\mathrm{R}$ ion from the latter generates intermediate 117, which undergoes intramolecular cyclization and leads to imidazole $\mathbf{1 1 8 .}$

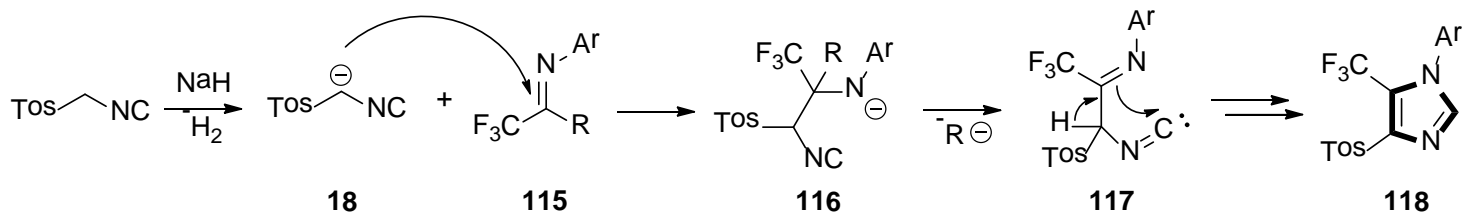

Scheme 32. A possible mechanism for the synthesis of imidazole-containing trifluoromethyl group.

\section{Other van Leusen Imidazole Synthesis}

In 2015, Fodili and collaborators described the synthesis of a 1,4-disubstituted 5-methylimidazole 121. As shown in Scheme 33, compound 121 was prepared by reacting enamine 119 with TosMIC 18, under the presence of tert-butylamine and a catalytic amount of bismuth (III) triflate in methanol. In this research, it was the first example of a usual rearrangement in the van Leusen imidazole synthesis and showed that the imidazole ring system can be prepared through reaction with TosMIC and a tautomeric enamine, to form a secondary ketamine. The possible mechanism involves the formation of the van Leusen imidazoline intermediate, followed by a $\mathrm{C}-\mathrm{C}$ bond cleavage and then subsequent tosyl substitution [56]. 


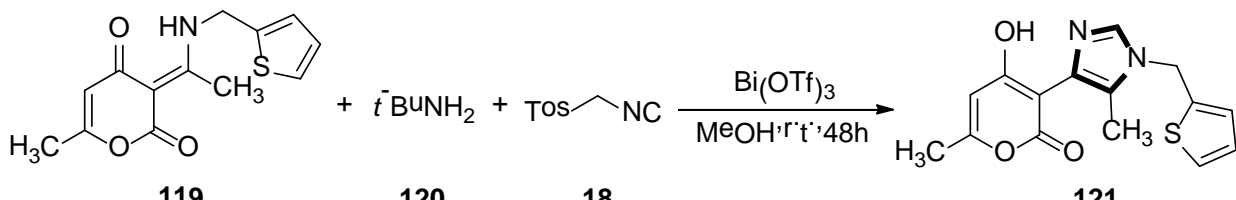

Scheme 33. The first example of an unusual rearrangement in the van Leusen imidazole synthesis.

In 2019, the Suresh group demonstrated the formation of imidazoles in the presence of water as a solvent and a base-free condition. The reaction of dihydro $\beta$-carboline imines 122 and $p$-toluenesulfonylmethyl isocyanides 18 formed the corresponding substituted $N$-fused imidazo 6,11-dihydro $\beta$-carboline derivatives 123, with good yields under mild and green condition (Scheme 34) [57].

$$
\begin{aligned}
& \text { Genera| van Leusen ¡midazole reaction: }
\end{aligned}
$$

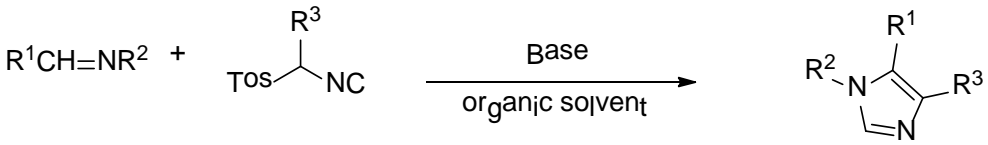

suresh's work:

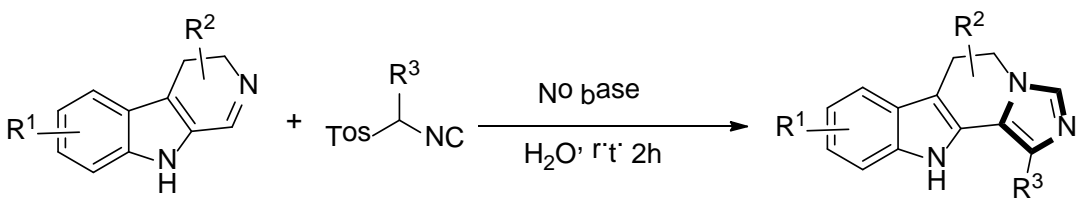

122

18

123

Scheme 34. The base-free van Leusen imidazole synthesis of cyclic imines in water.

A possible mechanism for the present metal- and base-free imidazole framework is shown in Scheme 35. Initially, the precursor dihydro $\beta$-carboline imine $\mathbf{1 2 2}$ acts as a base that captures proton from TosMIC 18, to provide a C-nucleophile, which would add to the dihydro $\beta$-carboline imine 122, and then be cyclized to form the intermediate 125 through the intermediate 124. Another molecule of the starting dihydro $\beta$-carboline imine 122 captures a proton from intermediate 125, then removes the tosyl group, which might result in the construction of imidazole derivative 123. Subsequently, the product imidazole 123 might also act as a base following the rational reaction mechanism, as described in Scheme 35 .

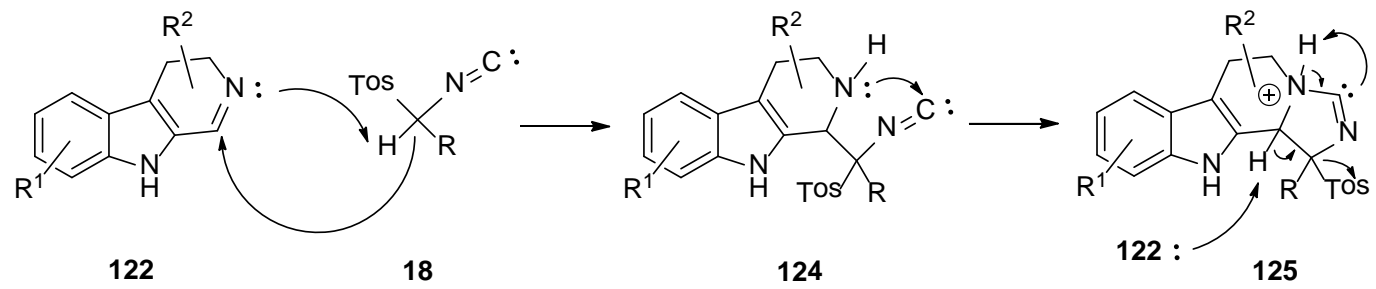<smiles>[R]CN1CCc2c([nH]c3ccccc23)-c2c([R])ncn2C1</smiles>

Scheme 35. A possible mechanism for the base-free van Leusen imidazole synthesis. 
At the same year, Necardo et al. found an unusual multicomponent synthesis of 4-tosyl-1arylimidazoles 127, by considering aryl azides as the electrophilic partners for the TosMIC 18-mediated van Leusen cycloaddition. In this transformation, it is the first example of the reaction of two TosMIC molecules participating in van Leusen imidazole synthesis (Scheme 36) [58].

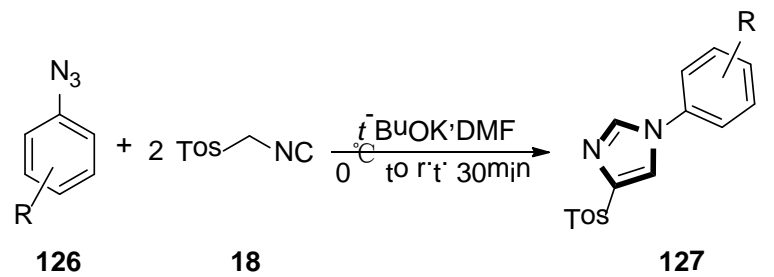

Scheme 36. Synthesis of $\mathbf{1 2 7}$ by van Leusen imidazole synthesis with two TosMIC.

A plausible scenario for the MCR is shown in Scheme 37. In the initiation step, the TosMIC anion attacks $N-3$ of the azide 128 to produce intermediate 129. Then, N-1 intercepts the isocyanide in a 6-endo-trig cyclization to form anion 130, which is quenched by a proton source to give 131 . Owing to its instability, compound 131 processes a [4+2] cycloreversion to formation 132, with a loss of nitrogen. Subsequently, the imine of $\mathbf{1 3 2}$ passes through an attack by a second molecule of the TosMIC anion, followed by ring closure, to produce 133. At this point, after protonation, intermediate 134 regains aromaticity via a base-assisted mechanism, with the expulsion of the most acidic proton and loss of hydrogen cyanide and sulfinate. Under strong basic condition, excess $t$-BuOK deprotonates the newly formed hydrogen cyanide, avoiding the release of toxic $\mathrm{HCN}$. It is worth noting that the two molecules of TosMIC partake in the reaction mechanism in two different paths, with the second molecule in Scheme 37 undergoing a fragmentation resulting in the incorporation of a $\mathrm{C}-\mathrm{H}$ into the target molecule.

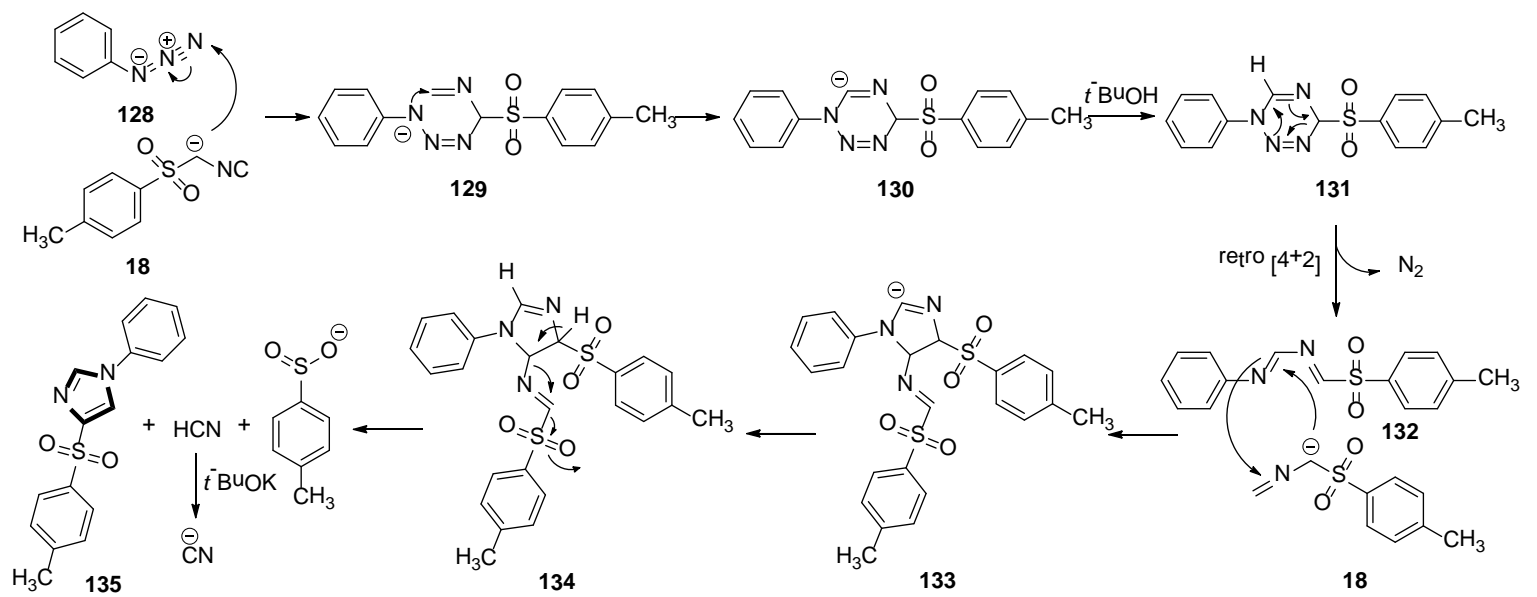

Scheme 37. A plausible scenario for the van Leusen imidazole synthesis with two TosMIC molecules.

In 2019, the one-pot three-component van Leusen chemistry was used for the DNA-encoded libraries (DELs) synthesis by the Staz group, which provided the first published DNA-compatible approach to form unusual highly functionalized imidazoles. The target DEL productions $\mathbf{1 3 8}$ were obtained from the aldehyde functionalized DNA molecule 136, amine 137, and TosMIC derivatives 18 by the van Leusen reaction. Moreover, a wide variety of amines, commercial TosMIC molecules and aldehyde as the variety element in the three ingredients heterocyclization were investigated under an optimized condition, respectively. This transformation meaningfully expanded the application of van Leusen imidazole synthesis and DNA compatible chemistries (Scheme 38) [59]. 


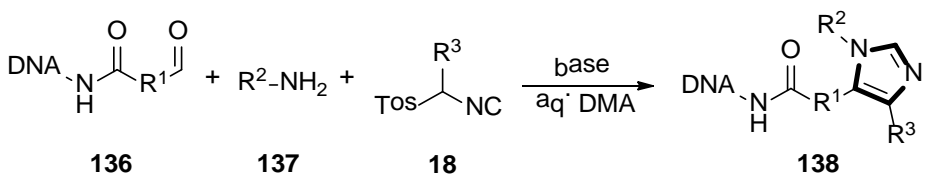

Scheme 38. DNA-compatible van Leusen imidazole heterocyclization.

\section{Conclusions}

In summary, under the in-depth research and application in imidazole-based medicinal chemistry and the progress in other disciplines—such as cell biology, molecular biology, pharmacology, and organic chemistry - an increasing number of imidazole-containing drugs with lower toxic, better efficacy, superior pharmacokinetic characteristics, effective pathologic probes and diagnostic agents would be used in clinics. This could make remarkable contributions for the protection of mankind's health. Therefore, the van Leusen imidazole synthesis based on TosMICs will play an increasingly central part in the synthesis of bioactive compounds as clinic drugs in drug design and synthesis. We could focus on the changing of the various aldimine groups and TosMIC derivatives in the van Leusen reaction to modify the imidazole derivatives in future. Above all these have clearly indicated the infinite potentiality of van Leusen imidazole synthesis in medicinal chemistry. Additionally, we hope this review would build a full foundation and reference source which would open up new thoughts for researchers to focus on in imidazole-based medicinal molecule design and synthesis chemistry.

Author Contributions: All authors wrote the paper. All authors have read and agreed to the published version of the manuscript.

Funding: Financial support of this research provided by the Science and Technology Planning Project of the Jilin Province (20160414015GH) is greatly acknowledged.

Conflicts of Interest: The authors declare no conflict of interest.

\section{References}

1. Mishra, R.; Ganguly, S. Imidazole as an anti-epileptic: An overview. Med. Chem. Res. 2012, 21, 3929-3939. [CrossRef]

2. Zhang, L.; Peng, X.M.; Damu, G.L.; Geng, R.X.; Zhou, C.H. Comprehensive review in current developments of imidazole-based medicinal chemistry. Med. Res. Rev. 2014, 34, 340-437. [CrossRef]

3. Gaba, M.; Mohan, C. Development of drugs based on imidazole and benzimidazole bioactive heterocycles: Recent advances and future directions. Med. Chem. Res. 2015, 25, 173-210. [CrossRef]

4. Fan, Y.L.; Jin, X.H.; Huang, Z.P.; Yu, H.F.; Zeng, Z.G.; Gao, T.; Feng, L.S. Recent advances of imidazole-containing derivatives as anti-tubercular agents. Eur. J. Med. Chem. 2018, 150, 347-365. [CrossRef] [PubMed]

5. Daraji, D.G.; Prajapati, N.P.; Patel, H.D. Synthesis and applications of 2-substituted imidazole and its derivatives: A review. J. Heterocycl. Chem. 2019, 56, 2299-2317. [CrossRef]

6. Khabnadideh, S.; Rezaci, Z.; Khalafi, N.A.; Motazedian, M.H.; Eskandari, M. Synthesis of metronidazole derivatives as antigiardiasis agents. DARU 2007, 15, 17-20.

7. Satyanarayana, V.; Sivakumar, A. An efficient and novel one-pot synthesis of 2,4,5-triaryl-1H-imidazoles catalyzed by $\mathrm{UO}_{2}\left(\mathrm{NO}_{3}\right)_{2} \cdot 6 \mathrm{H}_{2} \mathrm{O}$ under heterogeneous conditions. Chem. Pap. 2011, 65, 519-526. [CrossRef]

8. Van den, B.H. Biochemical effects of miconazole on fungi-I Effects on the uptake and/or utilization of purines, pyrimidines, nucleosides, amino acids and glucose by Candida albicans. Biochem. Pharmacol. 1974, 23, 887-899.

9. Carrilo-Muñoz, A.J.; Tur, C.; Torres, J.; Seymour, A.C. In-Vitro antifungal activity of sertaconazole, bifonazole, ketoconazole, and miconazole against yeasts of the Candida genus. J. Antimicrob. Chemother. 1996, 37, 815-819. [CrossRef]

10. Che, H.; Tuyen, T.N.; Kim, H.P.; Park, H. 1,5-Diarylimidazoles with strong inhibitory activity against COX-2 catalyzed PGE 2 production from LPS-induced RAW 264.7 cells. Bioorg. Med. Chem. Lett. 2010, 20, 4035-4037. [CrossRef] 
11. Forster, L.; Ludwig, J.; Kaptur, M.; Bovens, S.; Elfringhoff, A.S.; Holtfrerich, A.; Lehr, M. 1-Indol-1-yl-propan-2ones and related heterocyclic compounds as dual inhibitors of cytosolic phospholipase $\mathrm{A}_{2} \alpha$ and fatty acid amide hydrolase. Bioorg. Med. Chem. 2010, 18, 945-952. [CrossRef] [PubMed]

12. Ren, J.S.; Nichols, C.; Bird, L.E.; Fujiwara, T.; Sugimoto, H.; Stuart, D.I.; Stammers, D.K. Binding of the second generation non-nucleoside inhibitor S-1153 to HIV-1 reverse transcriptase involves extensive main chain hydrogen bonding. J. Biol. Chem. 2000, 275, 14316-14320. [CrossRef]

13. Zhan, P.; Liu, X.; Zhu, J.; Fang, Z.; Li, Z.; Pannecouque, C.; Clercq, E.D. Synthesis and biological evaluation of imidazole thioacetanilides as novel non-nucleoside HIV-1 reverse transcriptase inhibitors. Bioorg. Med. Chem. 2009, 17, 5775-5781. [CrossRef] [PubMed]

14. Valdez, C.A.; Tripp, J.C.; Miyamoto, Y.; Kalisiak, J.; Hruz, P.; Andersen, Y.S.; Brown, S.E.; Kangas, K.; Arzu, L.V.; Davids, B.J.; et al. Synthesis and electrochemistry of 2-ethenyl and 2-ethanyl derivatives of 5-nitroimidazole and antimicrobial activity against Giardia lamblia. J. Med. Chem. 2009, 52, 4038-4053. [CrossRef]

15. Kapoor, V.K.; Chadha, R.; Venisetty, P.K.; Prasanth, S. Medicinal significance of nitroimidazoles-Some recent advances. J. Sci. Ind. Res. 2003, 62, 659-665.

16. Josephy, P.D.; Palcic, B.; Skarsgard, L.D. In Vitro metabolism of misonidazole. Br. J. Cancer 1981, 43, $443-450$. [CrossRef]

17. Pectasides, D.; Yianniotis, H.; Alevizakos, N.; Bafaloukos, D.; Barbounis, V.; Varthalitis, J.; Dimitriadis, M.; Athanassiou, A. Treatment of metastatic malignant melanoma with dacarbazine, vindesine and cisplatin. Br. J. Cancer 1989, 60, 627-629. [CrossRef]

18. Kitbunnadaj, R.; Zuiderveld, O.P.; Christophe, B.; Hulscher, S.; Menge, W.M.; Gelens, E.; Snip, E.; Bakker, R.A.; Celanire, S.; Gillard, M.; et al. Identification of 4-(1H-imidazol-4(5)-ylmethyl)pyridine (immethridine) as a novel, potent, and highly selective histamine $\mathrm{H}_{3}$ receptor agonist. J. Med. Chem. 2004, 47, 2414-2417. [CrossRef]

19. Motawaj, M.; Arrang, J.M. Ciproxifan, a histamine $\mathrm{H}_{3}$-receptor antagonist/inverse agonist, modulates methamphetamine-induced sensitization in mice. Eur. J. Neurosci. 2011, 33, 1197-1204. [CrossRef]

20. Hille, U.E.; Zimmer, C.; Vock, C.A.; Hartmann, R.W. First selective CYP11B1 inhibitors for the treatment of cortisol-dependent diseases. ACS Med. Chem. Lett. 2011, 2, 2-6. [CrossRef]

21. Salerno, L.; Modica, M.N.; Romeo, G.; Pittala, V.; Siracusa, M.A.; Amato, M.E.; Acquaviva, R.; Di Giacomo, C.; Sorrenti, V. Novel inhibitors of nitric oxide synthase with antioxidant properties. Eur. J. Med. Chem. 2012, 49, 118-126. [CrossRef] [PubMed]

22. Van Leusen, A.M.; Wildeman, J.; Oldenziel, O.H. Base-induced cycloaddition of sulfonylmethyl isocyanides to C,N double bonds. Synthesis of 1,5-disubstituted and 1,4,5-trisubstituted imidazoles from aldimines and imidoyl chlorides. J. Org. Chem. 1977, 42, 1153-1159. [CrossRef]

23. Ma, B.B.; Peng, Y.X.; Zhao, P.C.; Huang, W. cis and trans Isomers distinguished by imidazole $N$-alkylation after Debus-Radziszewski reaction starting from 2,7-di-tert-butyl-pyrene-4,5,9,10-tetraone. Tetrahedron 2015, 71, 3195-3202. [CrossRef]

24. Benincori, T.; Brenna, E.; Sannicolo, F. Studies on Wallach's imidazole synthesis. J. Chem. Soc. Perkin Trans. 1993, 1, 675-679. [CrossRef]

25. Tandon, V.K.; Rai, S. $p$-Toluenesulfonylmethyl isocyanide: A versatile synthon in organic chemistry. Suljiur Rep. 2003, 24, 307-385.

26. Akritopoulou-Zanze, I. Isocyanide-based multicomponent reactions in drug discovery. Curr. Opin. Chem. Biol. 2008, 12, 324-331. [CrossRef]

27. Lujan-Montelongo, J.A.; Estevez, A.O.; Fleming, F.F. Alkyl sulfinates: Formal nucleophiles for synthesizing TosMIC analogs. Eur. J. Org. Chem. 2015, 7, 1602-1605. [CrossRef]

28. Mathiyazhagan, A.D.; Anilkumar, G. Recent advances and applications of $p$-toluenesulfonylmethyl isocyanide (TosMIC). Org. Biomol. Chem. 2019, 17, 6735-6747. [CrossRef]

29. Van Leusen, D.; van Leusen, A.M. Synthetic uses of tosylmethyl isocyanide (TosMIC). In Organic Reactions; Overman, L., Ed.; John Wiley \& Sons, Inc.: Hoboken, NJ, USA, 2001; Volume 57, pp. 417-666.

30. Frankowski, A.; Deredas, D.; Lenouen, D.; Tschamber, T.; Streith, J. On the way to glycoprocessing inhibitors. Synthesis of an imidazo-L-xylo-piperidinose derivative. Helv. Chim. Acta 1995, 78, 1837-1842. [CrossRef] 
31. Sisko, J. A one-pot synthesis of 1-(2,2,6,6-tetramethyl-4-piperidinyl)-4-(4-fluorophenyl)-5-(2-amino-4pyrimidinyl)-imidazole: A potent inhibitor of P38 MAP kinase. J. Org. Chem. 1998, 63, 4529-4531. [CrossRef]

32. Sisko, J.; Kassick, A.J.; Mellinger, R.; Filan, J.J.; Allen, A.; Olsen, M.A. An investigation of imidazole and oxazole syntheses using aryl-substituted TosMIC reagents. J. Org. Chem. 2000, 65, 1516-1524. [CrossRef] [PubMed]

33. Vanelle, P.; Meuche, J.; Maldonado, J.; Crozet, M.P.; Delmas, F.; Timon-David, P. Functional derivatives of 5-benzo[1,3]-5-yl-1-methyl-1H-imidazole-2-carbaldehyde and evaluation of leishmanicidal activity. Eur. J. Med. Chem. 2000, 35, 157-162. [CrossRef]

34. Gracias, V.; Gasiecki, A.F.; Djuric, S.W. Synthesis of fused bicyclic imidazoles by sequential van Leusen/ring-closing metathesis reactions. Org. Lett. 2005, 7, 3183-3186. [CrossRef] [PubMed]

35. Gracias, V.; Gasiecki, A.F.; Djuric, S.W. Synthesis of fused imidazo azepine derivatives by sequential van Leusen/enyne metathesis reactions. Tetrahedron Lett. 2005, 46, 9049-9052. [CrossRef]

36. Gracias, V.; Darczak, D.; Gasiecki, A.F.; Djuric, S.W. Synthesis of fused triazolo-imidazole derivatives by sequential van Leusen/alkyne-azide cycloaddition reactions. Tetrahedron Lett. 2005, 46, 9053-9056. [CrossRef]

37. Beebe, X.; Gracias, V.; Djuric, S.W. Synthesis of fused imidazo-pyridine and -azepine derivatives by sequential van Leusen/Heck reactions. Tetrahedron Lett. 2006, 47, 3225-3228. [CrossRef]

38. Gracias, V.; Gasiecki, A.F.; Pagano, T.G.; Djuric, S.W. Synthesis of fused imidazole rings by sequential van Leusen/C-H bond activation. Tetrahedron Lett. 2006, 47, 8873-8876. [CrossRef]

39. Beck, B.; Leppert, C.A.; Mueller, B.K.; Dömling, A. Discovery of pyrroloimidazoles as agents stimulating neurite outgrowth. QSAR Comb. Sci. 2006, 25, 527-535. [CrossRef]

40. Domling, A.; Beck, B.; Herdtweck, E.; Antuch, W.; Oefner, C.; Yehia, N.; Gracia-Marques, A. Parallel synthesis of arrays of 1,4,5-trisubstituted 1-(4-piperidyl)-imidazoles by IMCR: A novel class of aspartyl protease inhibitors. Arkivoc 2007, 2007, 99-109.

41. Fodili, M.; Nedjar-Kolli, B.; Garrigues, B.; Lherbet, C.; Hoffmann, P. Synthesis of imidazoles from ketimines using tosylmethyl isocyanide (TosMIC) catalyzed by bismuth triflate. Lett. Org. Chem. 2009, 6, 354-358. [CrossRef]

42. De Moliner, F.; Hulme, C. A van Leusen deprotection-cyclization strategy as a fast entry into two imidazoquinoxaline families. Tetrahedron Lett. 2012, 53, 5787-5790. [CrossRef] [PubMed]

43. Fallarini, S.; Massarotti, A.; Gesu, A.; Giovarruscio, S.; Zabetta, G.C.; Bergo, R.; Giannelli, B.; Brunco, A.; Lombardi, G.; Sorba, G.; et al. In silico-driven multicomponent synthesis of 4,5-and 1,5-disubstituted imidazoles as indoleamine 2,3-dioxygenase inhibitors. Med. Chem. Comm. 2016, 7, 409-419. [CrossRef]

44. Murugesh, V.; Harish, B.; Adiseshu, M.; Nanubolu, J.B.; Suresh, S. Tandem copper-catalyzed N-arylationcondensation and van Leusen reaction: Synthesis of 1,4-benzodiazepines and imidazobenzodiazepines (ImBDs). Adv. Synthesis Catal. 2016, 358, 1309-1321. [CrossRef]

45. Hogendorf, A.S.; Hogendorf, A.; Kurczab, R.; Satala, G.; Lenda, T.; Walczak, M.; Latacz, G.; Handzlik, J.; Kiec-Kononowicz, K.; Wieronska, J.M.; et al. Low-basicity 5-HT 7 receptor agonists synthesized using the van Leusen multicomponent protocol. Sci. Rep. 2017, 7, 1444. [CrossRef] [PubMed]

46. Hogendorf, A.S.; Hogendorf, A.; Popiolek-Barczyk, K.; Ciechanowska, A.; Mika, J.; Satala, G.; Walczak, M.; Latacz, G.; Handzlik, J.; Kiec-Kononowicz, K.; et al. Fluorinated indole-imidazole conjugates: Selective orally bioavailable $5-\mathrm{HT}_{7}$ receptor low-basicity agonists, potential neuropathic painkillers. Eur. J. Med. Chem. 2019, 170, 261-275. [CrossRef]

47. Saha, D.; Kaur, T.; Sharma, A. Facile construction of imidazo-benzothia-/oxazepines via quick and efficient van Leusen protocol. Asian J. Org. Chem. 2017, 6, 527-533. [CrossRef]

48. Brant, M.G.; Goodwin-Tindall, J.; Stover, K.R.; Stafford, P.M.; Wu, F.; Meek, A.R.; Schiavini, P.; Wohnig, S.; Weaver, D.F. Identification of potent indoleamine 2,3-dioxygenase 1 (IDO1) inhibitors based on a phenylimidazole scaffold. ACS Med. Chem. Lett. 2018, 9, 131-136. [CrossRef]

49. Kondaparla, S.; Manhas, A.; Dola, V.R.; Srivastava, K.; Puri, S.K.; Katti, S.B. Design, synthesis and antiplasmodial activity of novel imidazole derivatives based on 7-chloro-4-aminoquinoline. Bioorg. Chem. 2018, 80, 204-211. [CrossRef]

50. Savanur, H.M.; Kalkhambkar, R.G.; Laali, K.K. Libraries of C-5 substituted imidazoles and oxazoles by sequential van Leusen (vL)-Suzuki, vL-Heck and vL-Sonogashira in imidazolium-ILs with piperidine-appended-IL as base. Eur. J. Org. Chem. 2018, 38, 5285-5288. [CrossRef] 
51. Guan, Z.R.; Liu, Z.M.; Ding, M.W. New efficient synthesis of $1 H$-imidazo-[4,5-c]quinolines by a sequential van Leusen/Staudinger/aza-Wittig/carbodiimide-mediated cyclization. Tetrahedron 2018, 74, 7186-7192. [CrossRef]

52. Lammi, C.; Sgrignani, J.; Arnoldi, A.; Lesma, G.; Spatti, C.; Silvani, A.; Grazioso, G. Computationally driven structure optimization, synthesis, and biological evaluation of imidazole-based proprotein convertase subtilisin/kexin 9 (PCSK9) inhibitors. J. Med. Chem. 2019, 62, 6163-6174. [CrossRef] [PubMed]

53. Rashamuse, T.J.; Harrison, A.T.; Mosebi, S.; van Vuuren, S.; Coyanis, E.M.; Bode, M.L. Design, synthesis and biological evaluation of imidazole and oxazole fragments as HIV-1 integrase-LEDGF/p75 disruptors and inhibitors of microbial pathogens. Bioorg. Med. Chem. 2020, 28, 115210. [CrossRef]

54. Bunev, A.S.; Vasiliev, M.A.; Statsyuk, V.E.; Ostapenko, G.I.; Peregudov, A.S. Synthesis of 1-aryl-4-tosyl-5(trifluoromethyl)-1H-imidazoles. J. Fluor. Chem. 2014, 163, 34-37. [CrossRef]

55. Bunev, A.S.; Varakina, E.V.; Khochenkov, D.A.; Peregudov, A.S. 1-Imidoyl-1,2,3-benzotriazoles-Novel reagents for the synthesis of 1-aryl-5-trifluoromethylimidazoles. Russ. J. Org. Chem. 2019, 55, 493-497. [CrossRef]

56. Fodili, M.; Nedjar-Kolli, B.; Vedrenne, M.; Saffon-Merceron, N.; Lherbet, C.; Hoffmann, P. The first example of an unusual rearrangement in the van Leusen imidazole synthesis. Chem. Heterocycl. Compd. 2015, 51, 940-943. [CrossRef]

57. Satyam, K.; Murugesh, V.; Suresh, S. The base-free van Leusen reaction of cyclic imines on water: Synthesis of $N$-fused imidazo 6,11-dihydro $\beta$-carboline derivatives. Org. Biomol. Chem. 2019, 17, 5234-5238. [CrossRef] [PubMed]

58. Necardo, C.; Alfano, A.I.; Del Grosso, E.; Pelliccia, S.; Galli, U.; Novellino, E.; Meneghetti, F.; Giustiniano, M.; Tron, G.C. Aryl azides as forgotten electrophiles in the van Leusen reaction: A multicomponent transformation affording 4-Tosyl-1-arylimidazoles. J. Org. Chem. 2019, 84, 16299-16307. [CrossRef]

59. Geigle, S.N.; Petersen, A.C.; Satz, A.L. Development of DNA-Compatible van Leusen three-component imidazole synthesis. Org. Lett. 2019, 21, 9001-9004. [CrossRef]

(C) 2020 by the authors. Licensee MDPI, Basel, Switzerland. This article is an open access article distributed under the terms and conditions of the Creative Commons Attribution (CC BY) license (http://creativecommons.org/licenses/by/4.0/). 